\title{
PELATIHAN PEMBUATAN RUMPON BAGI KELOMPOK NELAYAN DI DESA LES, KECAMATAN TEJAKULA, KABUPATEN BULELENG
}

\author{
Kadek Rihendra Dantes \\ Jurusan Pendidikan Teknik Mesin, Fakultas Teknik dan Kejuruan \\ Universitas Pendidikan Ganesha \\ Singaraja, Indonesia \\ e-mail: rihendra79@gmail.com,
}

\begin{abstract}
Abstrak
Seperti yang diketahui bahwasanya kekayaan dan potensi perairan Indonesia sangatlah melimpah, yang menjadi salah satu potensi pengembang dan pendongkrak perekonomian masyarakat, khusunya para nelayan. Rumpon adalah salah satu jenis alat bantu penangkapan ikan yang dipasang dilaut, baik laut dangkal maupun laut dalam. Pembuatan rumpon ikan sebenarnya adalah salah satu cara untuk mengumpulkan ikan, dengan membentuk kondisi dasar laut menjadi mirip dengan kondisi karang-karang alami, rumpon membuat ikan merasa seperti mendapatkan rumah baru. Kegiatan ini dirancang dengan mengidentifikasi masalah yang timbul dengan menggunakan model Partisipatory Rural Apprasial (PRA). PRA adalah suatu teknik untuk menyusun dan mengembangkan program operasional dalam pembangunan tingkat desa. Metode ini ditempuh dengan memobilisasi sumber daya manusia dan alam setempat, serta lembaga lokal guna mempercepat peningkatan produktivitas, menstabilkan, dan meningkatkan pendapatan masyarakat serta mampu pula melestarikan sumberdaya setempat. Pelatihan pembuatan rumpon ikan ini mampu menjadi inspirasi bagi nelayan untuk membuat rumpon dan sekaligus mampu meningkatkan hasil tangkapan masyarakat khususnya nelayan di sekitar Desa Les. Kegiatan pelatihan pembuatan rumpon ini mampu didayagunakan dengan optimal untuk meningkatkan kesejahteraan warga masyarakat, khususnya bagi kelompok nelayan Segara Ening maupun masyarakat sekitar di kawasan Desa Les, Kecamatan Tejakula, Kabupaten Buleleng-Bali.
\end{abstract}

Kata kunci: nelayan, pelatihan, perikanan, rumpon.

\section{PENDAHULUAN}

Desa Les adalah sebuah desa yang terletak di wilayah utara Provinsi Bali, tepatnya di Kecamatan Tejakula, Kabupaten Buleleng. Potensi yang ada di Desa Les sangat prospektif untuk dikembangkan sebagai implementasi ideologi Ajeg Bali. Implementasi ideologi Ajeg Bali secara nyata yaitu pengembangan potensi yang sesuai dengan kearifan lokal masyarakatnya. Salah satu hal yang dapat dilakukan adalah dengan mengembangkan potensi perairan kelautan dikawasan Desa Les, mengingat mayoritas masyarakatnya berprofesi sebagai nelayan.

Belum banyaknya teknologi yang bisa diterapkan oleh masyarakat sekitar dikarenakan kurang tanggapnya mereka terhadap perkembangan media dan teknologi seperti sekarang ini. Masyarakat masih mengandalkan cara-cara tradisional untuk mendapatkan ikan, misalnya dengan memancing dan menebar jala dengan hasil yang tidak menentu. Hal tersebut tentu saja mengakibatkan masyarakat susah untuk memenuhi kebutuhan hidupnya sehari-hari, ditambah dengan terus meningkatnya harga-harga kebutuhan pokok seperti sekarang ini.

Seperti yang diketahui bahwasanya kekayaan dan potensi perairan Indonesia sangatlah melimpah, yang menjadi salah satu potensi pengembang dan pendongkrak perekonomian masyarakat, khusunya para nelayan. Dari profil Desa Les di atas dan beberapa ketersediaan sumber daya alam lokal potensial yang belum termanfaatkan secara maksimal, maka masalah yang ditemui di Desa Les, Kecamatan Tejakula, adalah sebagai berikut:

1. Warga Desa Les masih belum mampu memanfaatkan sumber daya alam lokal potensialnya untuk sebuah usaha yang memberikan prospek ekonomi yang baik. 
2. Ekonomi kreatif terutama di bidang perikanan yang berkembang sebagai mata pencaharian masyarakat setempat belum berkembang dengan baik karena beberapa kendala yaitu: (a) masih menggunakan cara tradisional yang kurang inovasi, (b) pemanfaatan potensi-potensi alam di daerah tersebut, (c) sumber daya manusia yang masih rendah, (d) penerapan media dan teknologi yang kurang diketahui dikalangan masyarakat setempat.

Oleh karena itu pada pengabdian ini, tim akan memberikan pelatihan dan penerapan rumpon bagi masyarakat setempat, khususnya yang bermata pencaharian sebagai nelayan. Rumpon adalah salah satu jenis alat bantu penangkapan ikan yang dipasang dilaut, baik laut dangkal maupun laut dalam. Pemasangan tersebut dimaksudkan untuk menarik gerombolan ikan agar berkumpul disekitar rumpon, sehingga ikan mudah untuk ditangkap. Rumpon dalam bahasa kelautan adalah karang buatan yang dibuat oleh manusia dengan tujuan sebagai tempat berkumpul ikan. Rumpon merupakan rumah buatan bagi ikan di dasar laut yang dibuat secara sengaja dengan menaruh berbagai jenis barang di dasar laut seperti ban, dahan dan ranting dengan pohonnya sekaligus. Barangbarang tersebut dimasukkan dengan diberikan pemberat berupa beton, batubatuan dan penberat lainnya sehingga posisi dari rumpon tidak bergerak karena arus laut. Barang-barang yang dimasukkan kedalam laut dapat terus ditambah secara berlanjut untuk menambah massa rumpon.

Tidak dapat dipungkiri bahwa akhirakhir ini penggunaan rumpon sebagai alat bantu penangkapan ikan semakin banyak digunakan oleh para pelaku utama penangkapan ikan (nelayan) maupun pelaku usaha bidang penangkapan ikan. Hal tersebut dikarenakan rumpon memberikan manfaat yang cukup nyata dalam upaya peningkatan hasil tangkapan ikan. Disamping itu rumpon juga dapat membantu dalam penangkapan ikan dengan menggunakan berbagai alat tangkap ikan, baik alat tangkap ikan yang aktif (seperti purse seine) maupun alat tangkap pasif (pancing, dan lain lain).

Pembuatan rumpon ikan sebenarnya adalah salah satu cara untuk mengumpulkan ikan, dengan membentuk kondisi dasar laut menjadi mirip dengan kondisi karang-karang alami, rumpon membuat ikan merasa seperti mendapatkan rumah baru. Meski untuk mengetahui keberhasilanya dibutuhkan waktu yang tidak sedikit sekitar 3- 6 bulan namun usaha pembuatan rumpon ini merupakan solusi terbaik meningkatkan hasil perikanan di laut.

Agar kepemilikkan rumpon tidak tertukar atau hilang, maka diberi tanda, misalnya dengan bendera, pelampung, cermin atau tanda lain sesuai keinginan pemiliknya. Pembuatan rumpon selain untuk diambil hasil ikannya untuk keperluan sendiri, dapat juga disewakan kepada para pemancing laut yang memang mencari kesenangan mencari ikan di lokasi yang banyak ikannya. Para pemancing yang memang membutuhkan hot spot memancing yang bagus dapat menyewa pemilik rumpon ini sebagai alternatif memancing yang cukup mudah.

Terdapat 3 jenis rumpon, yaitu:

1. Rumpon Perairan Dasar adalah alat bantu penangkapan ikan yang dipasang dan ditempatkan pada dasar perairan laut.

2. Rumpon Perairan Dangkal adalah alat bantu penangkapan ikan yang dipasang dan ditempatkan padaperairan laut dengan kedalaman sampai dengan 200 meter.

3. Rumpon Perairan Dalam adalah alat bantu penangkapan ikan yang dipasang dan ditempatkan pada perairan laut dengan kedalaman diatas 200 meter.

Dengan makin majunya rumpon telah menjadi salah satu alternatif untuk menciptakan daerah penangkapan buatan dan manfaat keberadaannya cukup besar. Sebelum mengenal rumpon, nelayan menangkap ikan dengan cara mengejar ikan atau menangkap kelompok ikan di laut, kini dengan makin berkembangnya rumpon maka pada saat musim penangkapan, lokasi penangkapan menjadi pasti di suatu tempat. Dengan telah ditentukan daerah penangkapan 
maka tujuan penangkapan oleh nelayan dapat menghemat bahan bakar, karena mereka tidak lagi mencari dan menangkap kelompok renang ikan dengan menyisir lautan yang luas yang tentunya akan menghabiskan biaya yang lebih besar.

Adapun tujuan dan manfaat yang di dapat dari pelaksanaan kegiatan desa binaan ini adalah sebagai berikut:

1. Masyarakat dapat memanfaatkan media dan teknologi untuk membantu meningkatkan penghasilan mata pencaharian mereka sebagai nelayan. Media dan teknologi itu nantinya bisa diadopsi dan diterapkan dengan mudah oleh para nelayan.

2. Masyarakat mampu mengembangkan dan meningkatkan penghasilannya, sehingga kesejahteraan ekonomi masyarakat bisa terpenuhi.

Berdasarkan analisis situasi serta tujuan dan manfaat kegiatan yang dilaksanakan, maka target luaran dari kegiatan yang dilaksanakan adalah:

1. Menghasilkan masyarakat yang mampu memanfaatkan media dan teknologi yang berkembang, sehingga dapat dikelola dengan lebih optimal.

2. Menghasilkan suatu cara yang memiliki ciri khas dan memiliki aspek kearifan lokal untuk meningkatkan kesejahteraan masyarakat di Desa Les.

\section{METODE}

Kegiatan ini dirancang dengan mengidentifikasi masalah yang timbul dengan menggunakan model Partisipatory Rural Apprasial (PRA). Partisipatory Rural Apprasial (PRA) adalah suatu teknik untuk menyusun dan mengembangkan program operasional dalam pembangunan tingkat desa. Metode ini ditempuh dengan memobilisasi sumber daya manusia dan alam setempat, serta lembaga lokal guna mempercepat peningkatan produktivitas, menstabilkan, dan meningkatkan pendapatan masyarakat serta mampu pula melestarikan sumberdaya setempat. Bertolak dari konsep Partisipatory Rural Apprasial (PRA), maka tahapan kegiatan dalam model ini adalah melaksanakan identifikasi masalah setiap perumusan program maupun pendanaannya dilaksanakan secara terarah dengan berpihak dan melibatkan masyarakat di
Desa Les. Dengan demikian dalam merumuskan masalah, mengatasi masalah, penentuan proses dan kriteria masalah harus mengikutsertakan atau bahkan ditentukan oleh masyarakat/kelompok sasaran.

Dengan penggunaan model pendekatan diatas diharapkan akan: (1) dikenalnya masalah secara tepat/efektif sesuai dengan persepsi, kehendak, dan ukuran/kemampuan serta kebutuhan masyarakat tempat dilaksanakannya kegiatan, (2) tumbuhnya kekuatan (empowering) masyarakat atau kelompok sasaran dalam pengalaman merancang, melaksanakan, mengelola, dan mempertanggungjawabkan upaya peningkatan/pertumbuhan diri dan ekonominya, dan (3) efektifitas dan efesiensi penggunaan sumber daya manusia pada masyarakat atau kelompok sasaran.

Selanjutnya melalui analisis akan terinventarisir keterbatasan dan keberadaan berbagai sumberdaya, sarana dan prasarana, maupun jenis-jenis usaha masyarakat. Disamping itu pula akan ditemukan berbagai jenis kesenjangan dan kemiskinan secara mendalam baik secara natural, struktural, ataupun kultural.

Desain kegiatan adalah kerangka konseptual pelaksanaan kegiatan. Kegiatan ini akan dilaksanakan dengan model Enthrepreneurship Capacity Building (ECB) dan Technology Transfer (TT) serta dengan menerapkan Teknologi Tepat Guna (TTG). Model Enthrepreneurship Capacity Building (ECB) terkait dengan kemampuan berwirausaha dari masyarakat, dengan model ini kedepannya diharapkan: (1) memberikan wawasan, sikap, dan keterampilan usaha, (2) memberikan peluang, (3) memfasilitasi (modal pinjaman dsb.), dan (4) memonitor dan mengevaluasi bagaimana perkembangan usahanya.

Sementara itu model Technology Transfer (TT) dilakukan adalah dengan maksud agar masyarakat atau kelompok sasaran: (1) menguasai prinsip-prinsip penerapan teknologi terutama yang berkaitan dengan proyek yang sedang/akan dilaksanakan, (2) apabila 
teknologi yang digunakan dirasa sulit untuk diterapkan untuk menyelesaikan masalah/kebutuhan, maka ketua pelaksana mempunyai kewajiban untuk menyederhanakannya melalui penerapan Teknologi Tepat Guna (TTG), (3) melakukan kegiatan produksi dengan mereplikasi/memodifikasi dengan alat sederhana yang dapat menyelesaikan masalah/kebutuhan.

Pemberdayaan dan pembelajaran masyarakat/kelompok sasaran dilakukan dengan keaksaraan pelatihan dan pemahaman untuk mengembangkan mata pencaharian baik itu yang berkenaan dengan media/teknologi, desain, dan pegembangan. Dengan cara diatas maka masyarakat/kelompok sasaran akan dapat meningkatkan keterampilan yang dimiliki sehingga mampu bersaing dengan masyarakat lainnya. Dalam proses pemberdayaan dan pembelajaran akan dipandu dengan silabus sehingga terarah dalam mengembangkan usaha. Selain panduan silabus, juga disiapkan tenaga professional di bidang IImu Material dan Desain dari Jurusan Pendidikan Teknik Mesin, khususnya bahan-bahan yang nantinya digunakan sebagai sarana pembuatan media rumpon.

\section{HASIL DAN PEMBAHASAN}

Pelaksanaan kegiatan pengembangan Desa Binaan Pelatihan Pembuatan Rumpon bagi kelompok nelayan di Desa Les, Kecamatan Tejakula, Kabupaten Buleleng ini memiliki keterkaitan yang erat dengan Jurusan S1 Pendidikan Teknik Mesin, Fakultas Teknik dan Kejuruan, Universitas Pendidikan Ganesha, dikarenakan kegiatan ini merupakan penerapan teknologi di bidang Teknik Mesin khususnya IImu Bahan. Selain itu hal ini juga dilandasi oleh kualifikasi yang dimiliki oleh tim pelaksana yang berasal dari Jurusan Pendidikan Teknik Mesin.

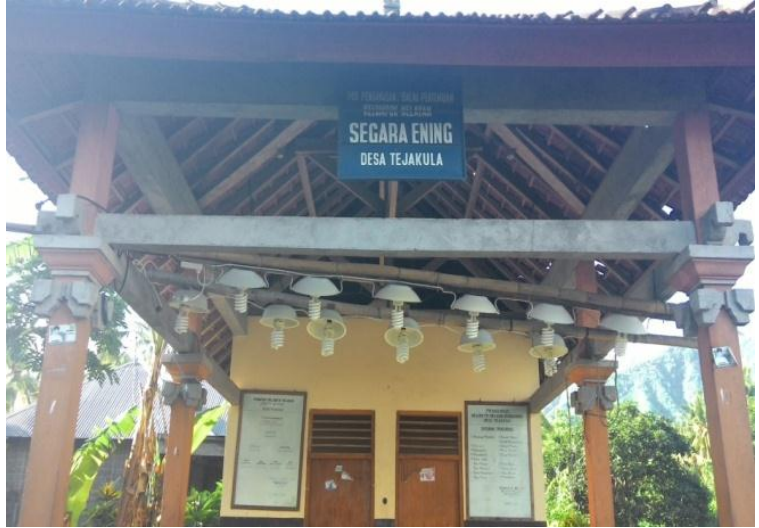

Gambar 1. Kelompok nelayan Segara

Ening, selaku mitra kegiatan P2M.

Pada pembuatan rumpon ini tim pelaksana bekerja sama dengan mitra yaitu kelompok nelayan Segara Ening di Desa Les, Kecamatan Tejakula-Buleleng. Ditempat ini tim pelaksana menyiapkan segala keperluan untuk pelatihan pembuatan rumpon, secara garis besar komponen tersebut adalah pelampung (float), tali (rope), pemikat (atractor), pemberat (sinker).

Secara ringkas, pelaksanaan pelatihan ini dipaparkan berdasarkan pembuatan komponen yang dilakukan.

\section{- Pelampung}

Pelampung merupakan komponen terpenting, karena mempengaruhi berapa lama suatu rumpon dapat bertahan ditengah laut. Syarat-syarat yang diperhatikan dalam pemilihan pelampung adalah:

a. Mempunyai kemampuan mengapung yang cukup baik (bagian yang mengapung di atas air 1/3 bagian),

b. Konstruksi cukup kuat,

c. Tahan terhadap gelombang dan air,

d. Mudah dikenali dari jarak jauh, dan

e. Bahan pembuatnya mudah didapat. Dengan memperhatikan syaratsyarat diatas maka dipilihlah pelampung dari bahan Styrofoam yang nantinya digunakan dalam pelatihan pembuatan rumpon ini. 


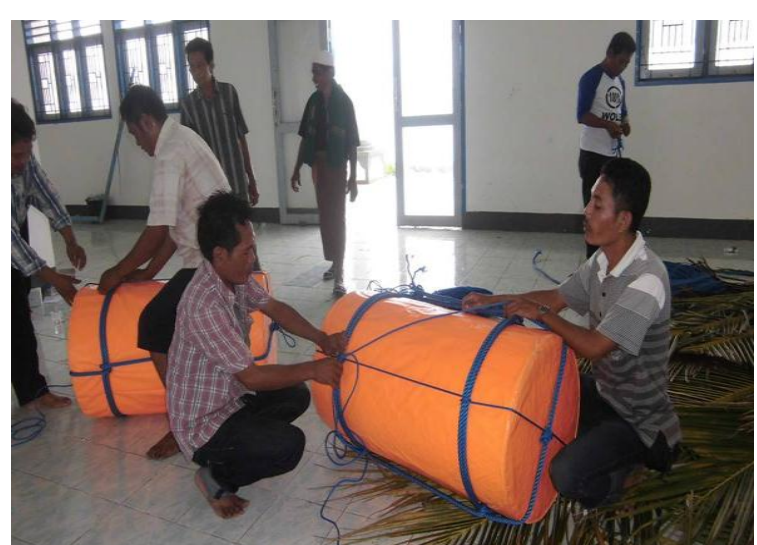

Gambar 2. Styrofoam yang digunakan dalam pelatihan pembuatan rumpon.

Pelampung ini diikat dengan menggunakan tali dan ditambah dengan beberapa batang bambu dengan disusun berbentuk persegi panjang dimana pelampung ditempatkan pada bagian tengah dari susunan bambu.

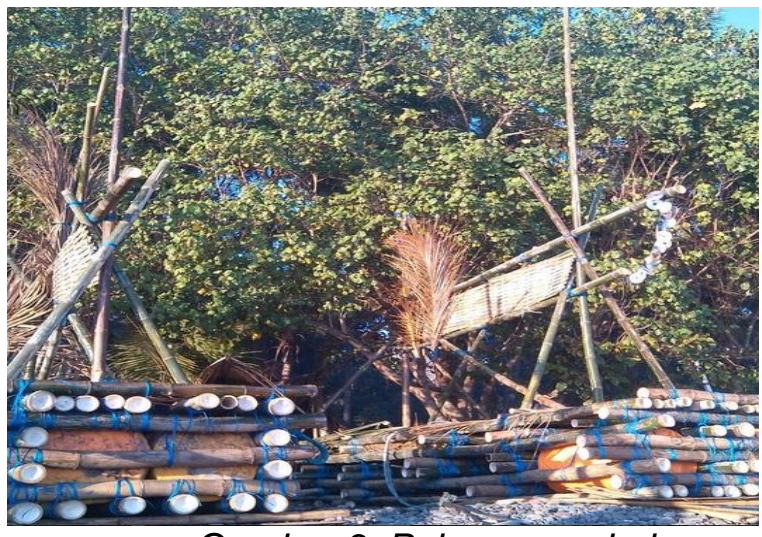

Gambar 3. Pelampung dari

styrofoam yang diletakkan ditengahtengah pelampung dari bambu dengan cara diikat dengan tali.

\section{- Pemikat}

Pembuatan pemikat yang tediri dari susunan yang berbentuk vertikal maupun horizontal, pemikat ini bertujuan untuk menarik ikan-ikan agar tertarik untuk datang dan tinggal di rumpon yang kita buat nantinya. Pembuatan pemikat ini dapat memanfaatkan bahan bekas yang tersedia, dimana selain sebagai pemikat juga dapat menjadi rumah dan melindungi ikan dari serangan ikan-ikan lainnya yang menjadi pemangsanya ataupun dari pergerakan arus dan ombak laut. Tali yang menghubungkan pemberat dan pelampung pada jarak tertentu disisipkan daun nyiur yang masih melekat pada pelepahnya setelah dibelah menjadi dua.

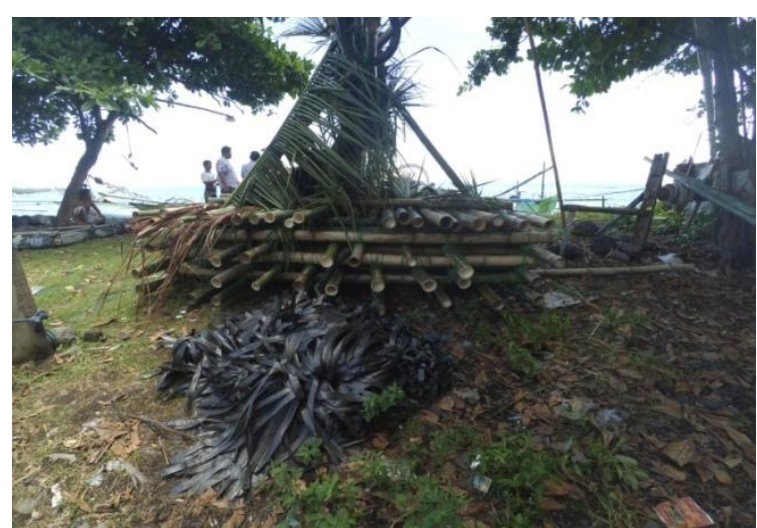

Gambar 4. Pemikat yang dibuat dari daun nyiur dan tali plastik.

Adapun beberapa persyaratan yang harus dimiliki oleh pemikat yang dapat digunakan adalah:

a. Mempunyai daya pikat yang baik terhadap ikan,

b. Tahan lama,

c. Mempunyai bentuk seperti posisi potongan vertical dengan arah ke bawah,

d. Melindungi ikan-ikan kecil, dan

e. Terbuat dari bahan yang kuat, tahan lama dan murah.

- $\quad$ Tali temali

Tali digunakan untuk menghubungkan pemberat dengan pelampung, selain itu tali menjadi tempat diikatkannya pemikat. Panjang tali bervariasi, tetapi pada umumnya adalah 1,5 kali kedalaman laut tempat rumpon tersebut ditanam/ditempatkan.

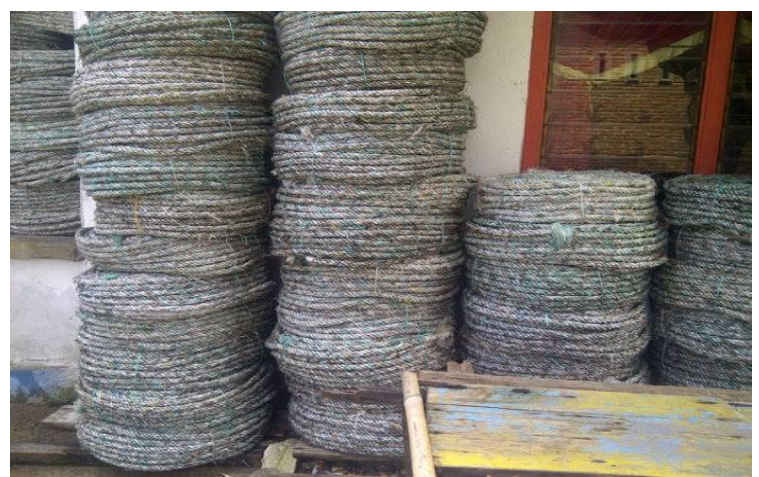

Gambar 5. Tali yang digunakan untuk menghubungkan pemberat dan pelampung. 
Melihat petingnya tali dalam suatu rumpon, maka adapun syarat-syarat yang harus dimiliki oleh tali yang digunakan adalah:

a. Terbuat dari bahan yang kuat dan tidak mudah busuk,

b. Harganya relatif murah,

c. Mempunyai daya apung yang cukup untuk mencegah gesekan terhadap benda- benda lainnya dan terhadap arus, dan

d. Tidak bersimpul (less knot).

\section{- Pemberat}

Pembuatan pemberat rumpon dari ban bekas yang dipadukan dengan bahan utama berupa beton yang di cor sehingga nantinya rumpon tidak hanyut terbawa arus ataupun ombak.

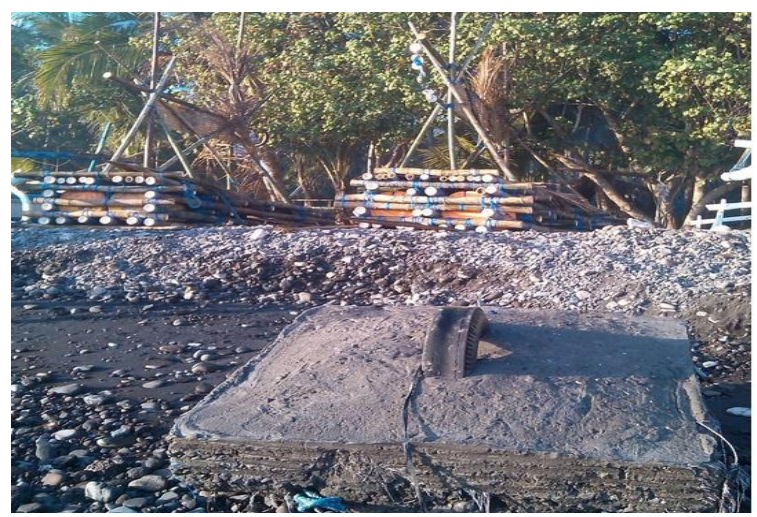

Gambar 6. Salah satu proses pembuatan rumpon (pembuatan pemberat).

Dalam pelatihan pembuatan rumpon ini, dipilih pemberat dari beton yang dicor adalah untuk memenuhi syarat-syarat seperti:

a. Bahannya murah, kuat dan mudah diperoleh

b. Massa jenisnya besar, permukaannya tidak licin dan dapat mencengkeram

Selanjutnya, rumpon-rumpon yang dibuat sudah siap untuk ditempatkan, penempatannya haruslah strategis dimana harus memperhitungkan potensi dimana ikan-ikan biasanya banyak dijumpai atau berkerumun. Hal ini adalah agar rumpon bisa dengan mudah dan cepat menjadi rumah/hunian bagi ikan- ikan yang kita sasar, dalah hal ini adalah ikan tuna.

Pada penempatannya, tim pelaksana bekerja sama dengan mitra yaitu kelompok nelayan Segara Ening di Desa Les, Kecamatan Tejakula-Buleleng untuk mengetahui lokasi strategis untuk memasang rumpon yang telah di buat. Hal ini dikarenakan tentunya nelayan disekitar lebih mengetahui dimana posisi yang strategis untuk menempatkan rumponrumpon, melihat keseharian mereka yang selalu bergelut dengan keadaan di laut.

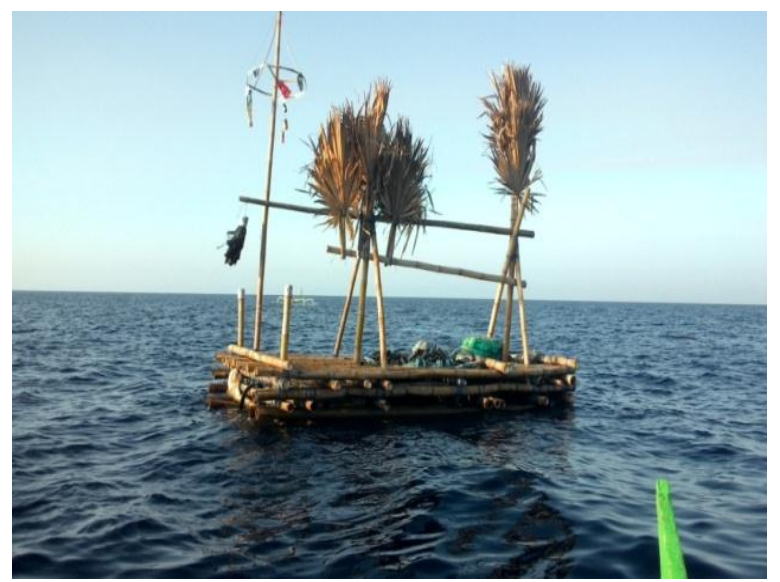

Gambar 7. Rumpon yang telah

dibuat, kemudian dibawa ke tengah laut yang ditempatkan pada suatu titik potensial.

Proses akhir dalam pengabdian pada masyarakat ini adalah membawa rumpon pada posisi yang telah dipilih dengan menggunakan perahu.

\section{SIMPULAN DAN SARAN}

Dari pengabdian pada masyarakat yang dilakukan oleh tim pelaksana, diimplementasikan kepada kelompok nelayan Segara Ening di Desa Les melalui pelatihan pembuatan rumpon. Dimana kegiatan pelatihan pembuatan rumpon ini diikuti pula oleh mahasiswa Jurusan Pendidikan Teknik Mesin, Universitas Pendidikan Ganesha Singaraja. Dipilihnya rumpon ini mengingat potensi penjualan dan pengolahan ikan sangatlah luas. Selain itu kandungan gizi dari ikan juga menjadi pertimbangan bagi masyarakat dalam memilih dan mengkonsumsi ikan.

Dengan demikian pelatihan pembuatan rumpon ikan ini kedepannya mampu menjadi inspirasi bagi para 
nelayan untuk membuat rumpon dan sekaligus mampu meningkatkan hasil tangkapan masyarakat khususnya nelayan di sekitar Desa Les. Diharapkan kegiatan pelatihan pembuatan rumpon ini mampu didayagunakan dengan optimal untuk meningkatkan kesejahteraan warga masyarakat, khususnya bagi kelompok nelayan Segara Ening maupun masyarakat sekitar di kawasan Desa Les, Kecamatan Tejakula, Kabupaten Buleleng-Bali.

\section{DAFTAR PUSTAKA}

Anonim. 1993. Status dan Rencana Pengembangan Budidaya Ikan di Perairan Umum di Propinsi Jambi. Makalah pada Pertemuan Teknis Pengendalian Budidaya Ikan di Perairan Umum, Jambi 1-2 September 1993. Dinas Perikanan Propinsi Jambi, Jambi.

Anonim. 1995. Pengembangan dan Pelestarian Sumber Daya Ikan Perairan Umum Secara Terpadu. Rapat Kerja Teknis Direktorat Jenderal Perikanan, Sukabumi 1415 Juli 1995. Direktur Bina Sumber Hayati, Sukabumi.

Kottelat, M., A.J. Whitten, S.N. Kartikasari \& S. Wiroatmodjo. 1993. Freshwater Fishes of Western Indonesia and Sulawesi. Edisi Dwi Bahasa InggrisIndonesia. Periplus Edition (HK) Ltd. Bekerjasama dengan Kantor Menteri $\mathrm{KLH}$, Jakarta, Indonesia.

Subani, W. 1986. Telaah Penggunaan Rumpon dan Payaos dalam Perikanan Indonesia. Jurnal Penelitian Perikanan Laut, BPPL, Jakarta, 35: 35-45

Direktorat Jenderal Perikanan, 1995. Penggunaan Payaos/Rumpon di Indonesia. Jakarta 11 hal.

Syandri, H. \& Agustedi. 1996. Optimalisasi Pemanfaatan Sumberdaya Perikanan untuk Usaha Budidaya yang Berwawasan Lingkungan. Makalah pada Pertemuan Teknis Pengendalian Budidaya Air Tawar, Ditjen Perikanan, Deptan. Bukittinggi, 09-10 Desember 1996.

Tim Pengkajian Rumpon Fakultas Perikanan Institut Pertanian Bogor. 1987. Laporan Akhir Survey
Lokasi dan Desain Rumpon di Perairan Ternate, Tidore, Bacan dan sekitarnya. Laporan. Jurusan Pemanfaatan Sumberdaya Perikanan Fakultas Perikanan. Institut Pertanian Bogor. 